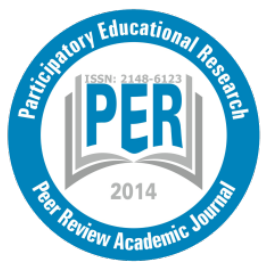

Participatory Educational Research (PER)

Vol. 6(2), pp. 93-102, December, 2019

Available online at http://www.perjournal.com

ISSN: 2148-6123

http://dx.doi.org/10.17275/per.19.15.6.2

\title{
The New Generation of Interactive Whiteboards: How Students Perceive and Conceptualize?
}

\author{
Fatih Saltan* \\ Amasya University, Department of Computer Education and Instructional Technology \\ Amasya, Turkey
}

Article history

Received:

10.09.2019

Received in revised form: 23.10.2019

Accepted:

29.10.2019

Key words:

Interactive whiteboard, teaching/learning

strategies, students' perceptions
The aim of the study was to investigate high school students' perceptions of the new generation of Interactive white board (IWB). At the same time, the question whether there were differences in perceptions with regard to certain variables such as gender and frequency of IWB use by teachers and students was examined. To achieve this aim, a parallel mixed method design was used. A total of 877 high school students participated in the study, comprising 410 female and 467 male students. The data were collected through an "Interactive Whiteboard Student Survey" and by open-ended questions. The quantitative data were analyzed using SPSS 20.0 for descriptive statistics and multivariate analysis of variance. Nvivo8 qualitative data analysis software was utilized for coding. Appropriate themes were developed from the related codes. The qualitative analysis revealed that about half of the students thought that IWBs were useful and effective tools for learning. There were seven themes and sub-themes which explained the contribution of IWBs to students' learning. The results of the MANOVA revealed no significant effect of gender and frequency of IWB use by teacher on high school students' perception of IWBs. On the other hand, there was a statistically significant difference in students' perception of IWBs based on frequency of IWB use by himself/herself, $F(6,1662)=3.11, \mathrm{p}<0.5$.

\section{Introduction}

With the widespread use of personal computers, computer- supported methods brought new approaches to education (e.g. Aiken, 1988). Later, new display technologies such as data projectors emerged (Bull \& Bull, 2005). The use of computers with data projectors became very common and a variety of methods emerged in this regard. Shortly after, interactive whiteboards (IWBs) began to be used in office settings and moved into educational environments in a rapid fashion (Greiffenhagen, 2004). In this way, computers, data projectors and boards were combined in classroom settings. In early studies, IWBs were defined as technological boards connected to a computer and a data projector (BECTA, 2004; Saltan \& Arslan, 2009; Schmid 2007; Smith, Higgins, Wall \& Miller, 2005). In recent studies, similar definitions have been articulated by educators and researchers (e.g. İpek \& Sözcü, 2016; Wong \& Goh, 2015). Some particular definitions highlighted the main characteristics of IWBs including their "large interactive display" (İpek \& Sözcü, 2016), carrying an "electronic touchable whiteboard" (Al-Qirim, 2014) and having "touch-sensitive interactive display" (Öz, 
2014). Innovation in personal computers and display technologies has influenced the technology behind IWBs. They have evolved into a separate device that is not connected to a computer or projector anymore. These devices, which can be referred to as 'new generation IWBs', incorporate a touch-sensitive LCD screen with a range of features and its own CPU. New generation IWBs have multi- touch-sensitive screens. In terms of both their appearance and the technology behind them, new generation IWBs can be compared to a huge tablet pc used by the teacher and whole class.

As these developments were taking place over the last decade, IWBs evolved into very common tools in some developed as well as developing countries. For instance, the UK, Turkey, the USA and Italy have been implementing major projects to provide all classrooms with IWBs and some other high-tech instructional tools (BECTA, 2004; Lee, 2010; Türel, 2010). Countries including China, Japan, Mexico, Malaysia, Russia, Singapore, and Taiwan are monitoring this technology integration process in classrooms and exhibiting their willingness to utilize IWBs in education (Yang, Wang \& Kao, 2012) to the full extent. This has required governments to invest substantial sums in the infrastructure for interactive whiteboards (Slay, Siebörger \& Hodgkinson-Williams, 2008). In fact, every second class has an IWB in Australia, Denmark and the Netherlands (McIntyre-Brown, 2011; Lee, 2010; Türel, 2011). What is more, interactive whiteboards have become popular at all instructional grades including K-12 and colleges (Haldane 2007; Smith, Higgins, Wall \& Miller, 2005).

The aforementioned countries appear to believe in the necessity of investing in instructional technologies to improve education in public schools (Bax, 2000; MoNE, 2010; Thomas and Schmid, 2010; Yang, Wang \& Kao, 2012). Wherever these projects have been instigated, IWBs have become a dependent part of the modern classroom.

While governments and schools were investing in the integration of IWBs into classrooms, researchers were conducting studies to understand the effects of IWBs on learning and upon the perceptions of teachers and students. Studies show that teachers and students generally have positive attitudes towards the use of IWBs in schools (İpek \& Sözcü, 2016; Akgün \&; Balta \& Duran, 2015; Koru-Yücekaya, 2015; Mathews-Aydinli \& Elaziz, 2010; Somyürek, Atasoy \& Özdemir, 2009). Several benefits of IWBs have been pinpointed in the relevant literature, which can be enlisted as: learner engagement and interactivity (Schmid \& Schimmack, 2010; Smith et al., 2005) visual quality, (Sad \& Ozhan, 2012; Slay et al., 2008 ) motivation (Higgins, 2010; Yıldız \& Tüfekçi ,2012) academic achievement, (Holmes, 2009; İpek\& Sözcü, 2016; Yang, Wang, \& Kao, 2012; Yorganc1, \& Terzioğlu, 2013); knowledge construction (Warwick, Hennessy \& Mercer, 2011) and classroom management (İpek \& Sözcü, 2016).

Some studies found that using IWBs in the classroom increased students' achievement levels in mathematics and science (Akgün \& Koru-Yücekaya, 2015; Bulut, \& Koçoğlu, 2012; Swan \& Marshall,2010). Other studies showed that students' attitudes toward the use of interactive whiteboard in math classes were positive (Jewitt, Moss \& Cardini, 2007; Kennewel, 2006).

In several countries, the IWB has become a fundamental part of the classroom. Various quantitative and qualitative studies have been conducted to investigate different aspects of their usage. In parallel with that, the technology of IWBs has advanced. So as to be able to investigate the full potential of new generation IWBs, a deeper understanding of students' perceptions towards these was required. However, a limited number of studies conducted with a valid instrument was observed in the bulk of literature. 
Instructors need to identify and exploit external motivation factors in order to achieve enjoyable and effective classes. The revolution of the new IWBs may seem as a technological improvement but in terms of classroom practices, they should also be improved and embraced by both shareholders- students and teachers. Smith et al. (2005) and Saltan and Arslan (2013) argue that the ease of operation of IWBs plays an essential role in users' attitudes towards their general use. Both teachers and students can only effectively use IWBs if they own the desired attitude. To that end, the way in which the new generation of interactive whiteboards is actually used in the classroom must be investigated thoroughly. Specifically, students' perceptions of the efficiency of IWBs, their contribution to their learning along with their motivation in the classroom, without neglecting any possible negative effects, should be examined in a careful manner.

\subsection{The purpose of the study}

The new generation of IWBs feature big touch-sensitive LCD screens and are technology- wise different and as regards to usability they differ from the previous ones. The aim of the study was to investigate high school students' perceptions of "new generation IWBs" and also to examine whether there were differences in the perceptions they hold with regard to particular variables, namely; gender, frequency of use by teachers and frequency of use by students. For the purpose of the study, the following specific research questions were addressed:

(1) What are high school students' perceptions of new generation IWBs?

(2) Do students' perceptions of IWBs differ when analyzed by gender, frequency of use by teachers or frequency of use by students?

(3) Are there some courses in which students prefer to use/not to use IWBs?

\section{Method}

\subsection{Research Design}

To explore high school students' perceptions of new generation IWBs, a parallel mixed method design was used. Using quantitative and qualitative approaches together balances out the weaknesses of the one method with the strengths of the another (Creswell, 2013). On the quantitative side, survey research was conducted (Fraenkel \& Wallen, 2006). Qualitative data was collected using an open-ended questionnaire and content analysis was carried out with a view to better understand students' perceptions on IWBs. The findings of both the qualitative and quantitative investigations are presented in the results section and colligated in the discussion part.

\subsection{Samples}

The participants in the study were 877 high school students, comprised of 410 female and 467 male students. The students were studying at five different public high schools in two large cities in Turkey. IWBs had been used for more than one year in all classrooms in the schools prior to the time of the study. Participants were all from levels 9,10 and 11.

\subsection{Data collection}

The data were collected through the "Interactive Whiteboard Student Survey" (IWSS) developed by Türel (2011). The IWSS consisted of twenty-six 5-point Likert-type items 
testing three factors - perceived efficiency of IWBs, perceived learning contribution and motivation, and the perceived negative effects of IWBs. Cronbach's Alpha coefficient of IWSS was calculated as 0.93 . Four open- ended questions prepared by the researcher were also resorted to while gathering qualitative data.

\subsection{Data analysis}

The quantitative data collected from the achievement test were analyzed using SPSS 20.0 for descriptive statistics and Multivariate analysis of variance (MANOVA). MANOVA was conducted to examine the influence of gender and IWB frequency of use by teachers (described as minimal use, moderate use, complete use) and IWB frequency of use by students (minimal use, moderate use, complete use) on students' perceived efficiency of IWBs, their perceived effect on learning contribution and motivation, and perceived negative effects of IWBs. The qualitative data, collected by the questionnaire, were analyzed using content analysis techniques (Miles\& Huberman, 1994). Nvivo8 qualitative data analysis software was utilized for coding. Appropriate themes were developed from the related codes. It was ensured that the themes were internally consistent and distinct from each other (Marshall \&Rossman, 2006).

\section{Results}

\subsection{What are the high school students' perceptions of new generation IWBs?}

For the sake of investigating students' perceptions of IWBs, descriptive statistics were calculated (see Table 3.1). Generally, students have a positive perception of IWBs pertaining to their efficiency and their contribution to their learning and motivation. The mean scores of male and female students were very close in all factors. When teachers and students' frequency of usage increased, students' mean score of perception overall increased.

Table 3.1 Descriptive Statistics

\begin{tabular}{|c|c|c|c|c|c|c|c|}
\hline & \multicolumn{3}{|c|}{ Factor1 } & \multicolumn{3}{|c|}{ Factor2 } & \multirow{2}{*}{$\begin{array}{l}\text { Factor3 } \\
\text { Std }\end{array}$} \\
\hline & $\mathrm{n}$ & M & Std & M & Std & M & \\
\hline \multicolumn{8}{|l|}{ Gender } \\
\hline Male & 454 & 3.15 & .95 & 3.26 & .81 & 3.28 & 1.03 \\
\hline Female & 395 & 3.10 & .93 & 3.17 & .86 & 3.09 & 1.15 \\
\hline \multicolumn{8}{|l|}{ Teacher Use } \\
\hline Minimal & 93 & 3.15 & 1.04 & 3.17 & .99 & 3.10 & 1.16 \\
\hline Moderate & 378 & 3.07 & .95 & 3.20 & .87 & 3.17 & 1.11 \\
\hline Complete & 378 & 3.16 & .90 & 3.26 & .77 & 3.20 & 1.08 \\
\hline \multicolumn{8}{|l|}{ Student Use } \\
\hline Minimal & 567 & 3.05 & .93 & 3.21 & .84 & 3.19 & 1.07 \\
\hline Moderate & 215 & 3.19 & .91 & 3.16 & .84 & 3.09 & 1.18 \\
\hline Complete & 67 & 3.58 & .97 & 3.54 & .81 & 3.36 & 1.12 \\
\hline
\end{tabular}

The qualitative analysis of the responses of participants to open-ended questions revealed that about half of the students thought that IWBs were useful and were effective tools for learning. Students mentioned some of the contributions of IWBs to their learning process. Some found IWBs to be neither efficient nor useful in this manner. The resulting categories are listed in Table 3.2. There were seven themes and sub-themes which explain the contribution of IWBs 
to students' learning.

Table 3.2 Themes and Categories

\begin{tabular}{cc}
\hline Themes/Categories & Frequency $(\mathrm{n}=610)$ \\
\hline Effective Learning & $360(\%)$ \\
Efficient & 160 \\
Multimedia & 120 \\
Easy & 80 \\
Motivation & $130(\%)$ \\
Environment & $60(\%)$ \\
Not Efficient & 40 \\
Distractions & 25 \\
Time-consuming & 10 \\
Other & 5 \\
Participation & $20(\%)$ \\
\hline
\end{tabular}

The participants stated that IWBs make it easy for them to learn. They commented that teachers save time using IWBs which enable use of multimedia materials. For example, one student uttered: "IWBs prevent the loss of time, make classes enjoyable-not boring-and allow us to better understand course topics."

Some participants also indicated that IWBs increase their motivation and allow students to actively participate in lessons. In this regard one student said: "Visuals on IWBs attract attention, otherwise courses might be boring. This helps us to understand well". Furthermore, it was indicated that IWBs create a technology- rich learning environment. They allow students to make presentations. Also, teachers make use of IWBs to create problem- solving activities in class.

\subsection{Do students' perceptions of IWBs differ when analyzed by gender, frequency of IWB use by the teacher and by the student?}

The results of the MANOVA revealed no significant effect of gender and frequency of IWB use by teacher on high school students' perception of IWBs. On the other hand, there was a statistically significant difference in students 'perception of IWBs based on frequency of use IWB by himself/herself, $F(6,1662)=3.11, p=.005$; Wilk's $\Lambda=0.978$, partial $\eta 2=$ .11. Frequency of use by students has a statistically significant effect on the perceived efficiency of IWBs $(F(2,833)=5.51 ; p=.004$; partial $\eta 2=.13)$ and on the perceived learning contribution $(\mathrm{F}(2,833)=5.11 ; \mathrm{p}=.006$; partial $\eta 2=.12)$ But frequency of use by students did not have a significant effect on the perceived negative effects of IWB.

Following MANOVA, Tukey's HSD method was used to compare groups concerning IWB frequency of use by students. Results showed that mean scores for the perceived efficiency of IWBs were statistically significantly different between minimal use and complete use $(\mathrm{p}<$ $.0005)$, and between moderate use and complete use $(\mathrm{p}=.007)$, yet not between minimal use and moderate use $(\mathrm{p}=.151)$. Perceived learning contribution and motivation scores were statistically significantly different between minimal use of IWBs and complete use $(p=.006)$, and between moderate use and complete use $(\mathrm{p}=.003)$, but not between minimal and moderate use $(\mathrm{p}=.742)$. 


\subsection{In which courses did students prefer to use/not to use IWBs?}

Students were asked in which courses they wanted to use IWBs and in which they did not. As seen in Table 3.3, geography was the most cited course in which students preferred to use IWBs. This was followed by history and English language. On the other hand, students did not want IWBs to be used in mathematics courses.

Table 3.3 The courses in which IWB was preferred to be used

\begin{tabular}{lll}
\hline Course & Should Use $(\mathrm{n}=877)$ & Should Not Use $(\mathrm{n}=877)$ \\
\hline Math & 239 & 453 \\
English Language & 492 & 129 \\
Geography & 621 & 99 \\
Physics & 215 & 227 \\
Chemistry & 247 & 201 \\
Biology & 347 & 118 \\
Literature & 398 & 189 \\
Turkish Language & 387 & 188 \\
Religious culture & 318 & 159 \\
History & 553 & 124 \\
Philosophy & 178 & 163 \\
All & 126 & 60 \\
\hline
\end{tabular}

The qualitative analysis of the responses of participants to open-ended questions revealed that about half the students thought that IWBs were effective in teaching social sciences. Some participants specified course names including history, geography and literature. They indicated that visualization in such courses makes lessons more effective and enjoyable. One student explained: “...for example, we can easily access all the maps in geography class. In literacy and some other courses, we watch educational movies. In English classes we do multiple choice and fill- in- the- blank activities".

On the other hand, around one quarter of the participants asserted that using IWBs in math and geometry courses, is not effective or meaningful. They highlighted that teachers have difficulties in writing on the IWB and managing the classroom simultaneously. To illustrate, one student underlined: "IWBs are not efficient for a math course. When using IWBs, noise levels cannot be managed in the classroom. While the teachers who are not familiar with IWBs are trying to use them, about ten minutes vanish doing nothing. This causes a decrease in the efficacy".

\section{Discussion and Conclusion}

This study aimed to explore high school students' perceptions of the new generation of IWBs. New generation IWBs have multi-touch- sensitive LCD screens. They differ in terms of the technologies employed and as per usability from the previous IWBs. The question whether there are differences in learner perceptions of IWBs related to certain variables: gender, frequency of use by the teacher and frequency of use by the student was examined. With this aim, a parallel mixed method design was applied which combined quantitative and qualitative approaches to balance out the weaknesses of one method with the strengths of the other.

The results of the qualitative analysis show that while about half the students indicated that IWBs are a useful and effective tool for learning, others found that IWBs were not efficient or useful. On the other hand, the participants mentioned several positive contributions of new 
generation IWBs to their learning. They stated that IWBs make it easy to learn. Teachers also saved time using IWBs by enabling the use of multimedia materials. Some participants also indicated that IWBs increase motivation and allow students to actively participate in lessons. In a relatively recent study, Akgun and Koru-Yucelkaya (2015) investigated perceptions of students and teachers who had more than three years of experience with IWBs. The results are similar to those of the present study. Teachers believe that interactive whiteboards have a positive effect on teaching and learning and that they also increase students' motivation. Together with that, Sad (2012) highlighted that failure on the part of teachers is the major factor limiting the use of IWBs in schools.

The results of the quantitative analysis showed that frequency of the use of IWBs has a statistically significant effect on the perceived efficiency and perceived contribution to learning on the part of the students. Comparison of the groups on the basis of frequency of IWB use by students showed that mean scores for the perceived efficiency of IWBs were statistically significantly different between the minimal use of IWBs and the complete use, and also between the moderate use and the complete use. This indicates that using IWBs in a frequent way shifts perceptions of students positively. Previous studies generally support this end result. They share that students and teachers have positive perceptions towards IWBs (Mathews-Aydinli \& Elaziz, 2010; Türel \& Johnson, 2012). Howbeit the results showed that gender is not a factor influencing students' perceptions about new generation whiteboards. In his study conducted with 167 male and female students, Oz (2014) found out that gender had no significant effect on students' perceptions.

Participants highlighted two main advantages of IWBs. Firstly, they seemed to provide effective learning via the use of multimedia and through the simplification of learning. Secondly, they enhance motivation. Students in particular mentioned that IWBs increase their motivation for actively taking part in lessons. Yildiz and Tufekci (2012) reported the same results. Also, the question whether students prefer to use new generation IWBs in specific classes was analyzed. It was witnessed that students preferred to use these in geography, English language teaching and history courses. Typically, geography involves the use of maps and diagrams. The boards provide students with an easy access to digital media and a vast range of visual material. The IWBs also enable teachers to use videos and animations. Thusly it is expected that students prefer IWB use in geography classes. In his study, Ates (2010) investigated the effect of using interactive whiteboards in geography education, from the perspectives of teachers and students. He showed that both teachers and students believe IWBs are an effective and motivating tool in geography lessons. Similarly, learning a foreign language is a complex process. Students benefit from watching videos and listening to audios. IWBs enable them to learn through such activities. Several studies conducted in the last decade support these results (Koenraad, Çelik, Higgins \& Hillier, 2015; López, 2010; Schmid, 2006; Schmid, 2007). On the other hand, a large number of participants asserted that math and geometry courses were not suitable for IWB use. They indicated that teachers had difficulty in writing on the IWB and managing the classroom at the same time.

Overall, this study showed that students in general have a positive perception toward IWBs in terms of their efficiency, contribution to their learning and to their motivation levels. Participants hence also highlighted that IWBs are a useful and effective tool for learning. These results are highly promising. Alongside that students perceived IWBs as effective for certain courses but not effective for some others. It is important that the perceptions of both teachers and students are considered to ensure the successful integration of technology into schools. Teachers are motivated to use IWBs in the classroom only if they believe that they 
are effective for learning.

\section{References}

Akgün, M., \& Koru Yücekaya, G. (2015). Teachers' perceptions and students' attitudes towards usage oF smart board (Ankara city sample). Qualitative Studies, 10(3), 1-11.

Al-Qirim, N. (2016). Smart board technology success in tertiary institutions: The case of the UAE University. Education and Information Technologies, 21(2), 265-281. doi: $10.1007 / \mathrm{s} 10639-014-9319-7$

Ateş, M. (2010). Ortaöğretim coğrafya derslerinde akıllı tahta kullanımı[The Using of Active Board at Secondary School Geography Lessons]. Marmara Coğrafya Dergisi[The journal of Marmara geography ], 22, 409-427.

Aiken, E. (1988). Moving into the Age of Computer-Supported Education: A Regional Experience in Nursing Education. Atlanta: Southern Regional Education Board.

Balta, N., \& Duran, M. (2015). Attitudes of Students and Teachers Towards The Use of Interactive Whiteboards in Elementary and Secondary School Classrooms. TOJET: The Turkish Online Journal of Educational Technology, 14(2), 15-23.

Bax, S. (2000). Putting technology in its place: ICT in modern foreign language teaching. In K. Field (Ed.), Issues in modern foreign languages teaching (pp. 199-210). London, England: Routledge Falmer.

BECTA. (2004). Getting the most from your interactive whiteboard: A guide for secondary schools. Coventry, UK: Becta. Date of Access: Jun 13, 2016, Retrieved from http://mirandanet.ac.uk/wp-content/uploads/2016/04/getting most_whiteboard secondary.pdf

Bull, G., \& Bull, G. (2005). Looking At Display Technologies. Learning \& Leading with Technology, 32(6), 40-43.

Bulut, İ., \& Koçoğlu, E. (2012). Sosyal Bilgiler Öğretmenlerinin Akıllı Tahta Kullanımına İlişkin Görüşleri (Diyarbakır İli Örneği)[ Social Studies Teachers' Views About Use Of Smart Board (Diyarbakır City Sample)]. Dicle Üniversitesi Ziya Gökalp Eğitim Fakültesi Dergisi[The journal of Dicle University Educational Faculty], 19, 242-258.

Creswell, J. W. (2013). Research design: Qualitative, quantitative, and mixed methods approaches (4th ed.). Thousand Oaks, CA: Sage.

Fraenkel, J. R., \& Wallen, N. E. (2006). How to design and evaluate research in education (6th ed.). New York: McGraw-Hill.

Greiffenhagen, C. (2004). Interactive whiteboards in mathematics education: possibilities and dangers. In H. Fujita, Y. Hashimoto, B. R. Hodgson, P. Y. Lee, S. Lerman, T. Sawada (Eds.), Proceedings of the Ninth International Congress on Mathematical Education.Date of Access: Feb 16, 2016. Retrieved From: https://dspace.lboro.ac.uk/2134/14308

Haldane, M. (2007). Interactivity and the digital whiteboard: weaving the fabric of learning. Learning, Media and Technology, 32(3), 257-270.

Higgins, S. (2010) The impact of interactive whiteboards on classroom interaction and learning in primary schools in the UK. In M. Thomas \& E. C. Schmid (Eds.), Interactive Whiteboards for Education: Theory, Research and Practice (pp. 86-101). Hershey, PA: IGI Global.

Holmes, K. (2009). Planning to teach with digital tools: Introducing the interactive whiteboard to pre-service secondary mathematics teachers. Australasian Journal of Educational Technology, 25(3), 351-365. 
Kennewel, S., (2006). Reflections on The Interactive Whiteboard Phenomenon: A Synthesis of Research from The U.K. Paper presented at The AARE Conference, 26-30 November, Adelaide, Auistralia.

Koenraad, T., Çelik, S., Higgins, A., \& Hillier, E. (2015). Promoting Interactive Whiteboard Use in Language and Vocational Education: A Tale of iTILT and SmartVET EU Projects. Žmogus ir žodis, 17(3), 146-154.

Lee, M. (2010). Interactive whiteboards and schooling: the context. Technology, Pedagogy and Education, 19(2), 133-141. doi: 10.1080/1475939X.2010.491215

López, O. S. (2010). The digital learning classroom: Improving English language learners' academic success in mathematics and reading using interactive whiteboard technology. Computers \& Education, 54(4), 901-915. doi: 10.1016/j.compedu.2009.09.019

Mathews-Aydinli, J., \& Elaziz, F. (2010). Turkish students' and teachers' attitudes toward the use of interactive whiteboards in EFL classrooms. Computer Assisted Language Learning, 23(3), 235-252. doi: 10.1080/09588221003776781

Marshall C., Rossman G. B. (2006). Designing qualitative research (4th ed.). Thousand Oaks, California: Sage Publication.

McIntyre-Brown, C. (2011). Understanding the next wave of technology innovation in education: UK. Date of Access: Jun 13, 2016, https://classtechnology.files.wordpress.com/2011/02/2011-01_futuresourceuk_understandingnext_wavetechnology.pdf

Miles, M. B., \& Huberman, A. M. (1994). Qualitative data analysis. An expanded sourcebook (2nd ed.). Thousand Oaks, California: Sage Publications.

MoNE (2010). FATIH Project: Movement of enhancing opportunities and improving technology. Retrieved from http://fatihprojesi.meb.gov.tr

İpek, İ., \& Sözcü, Ö. F. (2016). Preferences and Attitudes for Using Interactive Whiteboards in Different Courses and Learning. European Journal of Contemporary Education, 15(1), 173-184. doi: 10.13187/ejced.2016.15.173

Jewitt, C., Moss, G., \& Cardini, A. (2007). Pace, interactivity and multimodality in teachers' design of texts for interactive whiteboards in the secondary school classroom. Learning, Media and Technology, 32(3), 303-317. doi: 10.1080/17439880701511149

Öz, H. (2014). Teachers' and students' perceptions of interactive whiteboards in the English as a foreign language classroom. TOJET: The Turkish Online Journal of Educational Technology, 13(3). 126-147.

Saltan, F. \& Arslan, K. (2009). A New Teacher Tool, Interactive White Boards: A Meta Analysis. In I. Gibson, R. Weber, K. McFerrin, R. Carlsen \& D. Willis (Eds.), Proceedings of Society for Information Technology \& Teacher Education International Conference 2009, 2115-2120.

Saltan, F., \& Arslan, K. (2013) Teachers' Perception of Interactive White Boards: A Case Study. Mersin University Journal of the Faculty of Education, 9(2), 353-365.

Şad, S. N. (2012). An attitude scale for smart board use in education: Validity and reliability studies. Computers \& Education, 58(3), 900-907. doi: :10.1016/j.compedu.2011.10.017

Şad S. N., Özhan, U. (2012) Honeymoon with IWBs: A qualitative insight in primary students' views on instruction with interactive whiteboard. Computers \& Education, 59(4), 1184-1191. doi: 10.1016/j.compedu.2012.05.010

Schmid, E. C. (2006). Investigating the use of interactive whiteboard technology in the English language classroom through the lens of a critical theory of technology. Computer Assisted Language Learning, 19(1), 47-62. doi: 10.1080/09588220600804012 
Schmid, E. C. (2007). Enhancing performance knowledge and self-esteem in classroom language learning: The potential of the ACTIVote component of interactive whiteboard technology. System, 35(2), 119-133. doi: 10.1016/j.system.2007.01.001

Schmid, E. C., \& Schimmack, E. (2010). First Steps Toward a Model of Interactive Whiteboard Training for Language Teachers. In M. Thomas \& E. C. Schmid (Eds.), Interactive Whiteboards for Education: Theory, Research and Practice (pp. 197-214). Hershey, PA: IGI Global.

Slay, H., Siebörger, I., \& Hodgkinson-Williams, C. (2008). Interactive whiteboards: Real beauty or just "lipstick"?. Computers \& Education, 51(3), 1321-1341. doi: 10.1016/j.compedu.2007.12.006

Smith, H. J., Higgins, S., Wall, K., \& Miller, J. (2005). Interactive whiteboards: boon or bandwagon? A critical review of the literature. Journal of Computer Assisted Learning, 21(2), 91-101. doi: 10.1111/j.1365-2729.2005.00117.x

Somyürek, S., Atasoy, B., \& Özdemir, S. (2009). Board's IQ: What makes a board smart? Computers \& Education, 53(2), 368-374. doi: 10.1016/j.compedu.2009.02.012

Swan, P., \& Marshall, L. (2010). Revisiting mathematics manipulative materials. Australian Primary Mathematics Classroom, 15(2), 13-19.

Thomas, M., \& Schmid, E. C.(2010). Interactive whiteboards for education: Theory, research and practice. Hershey, PA: IGI Global.

Turel, Y. (2010). Developing Teachers' Utilization of Interactive Whiteboards. In D. Gibson \& B. Dodge (Eds.), Proceedings of Society for Information Technology \& Teacher Education International Conference 2010, 3049-3054.

Türel, Y. K. (2011). An interactive whiteboard student survey: Development, validity and reliability. Computers \& Education, 57(4), 2441-2450. doi: 10.1016/j.compedu.2011.07.005

Türel, Y. K., \& Johnson, T. E. (2012). Teachers' belief and use of interactive whiteboards for teaching and learning. Educational Technology \& Society, 15(1), 381-394.

Warwick, P., Hennessy, S., \& Mercer, N. (2011). Promoting teacher and school development through co-enquiry: Developing interactive whiteboard use in a 'dialogic classroom'. Teachers and Teaching: theory and practice, 17(3), 303-324. doi: 10.1080/13540602.2011.554704

Wong, K. T., Teo, T., \& Goh, P. S. C. (2015). Understanding the intention to use interactive whiteboards: model development and testing. Interactive Learning Environments, 23(6), 731-747. doi: 10.1080/10494820.2013.806932

Yang, K. T., Wang, T. H., \& Kao, Y. C. (2012). How an interactive whiteboard impacts a traditional classroom. Education as Change, 16(2), 313-332.

Yildiz, C., \& Tufekci, A. (2012). A study on the smart board usability in-classroom applications. Journal of Engineering and Natural Sciences, 30(4), 381-391.

Yorganc1, S., \& Terzioğlu, Ö. (2013). Matematik Öğretiminde Akıllı Tahta Kullanımının Başarıya ve Matematiğe Karşı Tutuma Etkisi[The Effect Of Usıng Interactıve Whiteboard In Mathematics Instruction On Achievement And Attitudes Toward Mathematıcs]. Kastamonu Eğitim Dergisi[Kastamonu Educational Journal], 21(3), 919930. 